\title{
Kebijakan Pemerintah Kabupaten Pacitan Dalam Pelestarian Museum Buwono Keling di Kecamatan Punung Kabupaten Pacitan
}

\author{
Rizky Nindya Nunggalsari ${ }^{1}$, Soebijantoro ${ }^{2}$ \\ ${ }^{1}$ Alumni Pendidikan Sejarah FKIP Universitas PGRI Madiun \\ ${ }^{2}$ Dosen Program Studi Pendidikan Sejarah FKIP Universitas PGRI Madiun
}

\begin{abstract}
Abstrak
Penelitian ini bertujuan untuk mendapatkan gambaran secara menyeluruh tentang kebijakan Pemerintah Kabupaten Pacitan dalam pelestarian Museum Buwono Keling di Kecamatan Punung Kabupaten Pacitan.

Pendekatan penelitian ini adalah kualitatif dengan jenis studi kasus. Sumber data yang digunakan adalah sumber data primer dan sekunder. Pengumupulan data menggunakan observasi wawancara, dokumentasi. Validasi yang digunakan adalah trianggulasi sumber. Analisis data menggunakan model interaktif Miles dan Huberman.

Hasil penelitian menunjukkan bahwa Museum Buwono Keling adalah museum arkeologi yang berada di Dukuh Krajan Kulon Desa Mantren Kecamatan Punung Kabupaten Pacitan. Museum ini dibangun pada bulan April tahun 1995 oleh suaka peninggalan sejarah purbakala Jawa Timur, dan difungsikan pada tahun 1996 yakni sebagai tempat penyimpanan peninggalan prasejarah. Peranan Pemerintah Kabupaten Pacitan dalam pengelolaan dan pelestarian Museum Buwono Keling dibutuhkan, agar Museum tetap terjaga dan terlestarikan. Berkaitan dengan hal itu diterapkan kebijakan dalam pengelolaan Museum. Namun kebijakan yang telah disepakati belum terealisasikan dengan baik. Kenyataannya Pemerintah Kabupaten Pacitan kurang tanggap atau tidak mempedulikan keberadaan Museum Buwono Keling. Padahal museum tersebut dapat menjadi suatu objek wisata yang tidak hanya mempunyai unsur rekreatif tapi memiliki unsur edukatif terutama mengenai kehidupan pra sejarah yang berhubungan dengan awal peradaban manusia.
\end{abstract}

Kata Kunci: Kebijakan, Pelestarian, Museum Buwono Keling

\section{Pendahuluan}

Indonesia merupakan negara

kepulauan yang kaya akan budaya. Namun sayang, khalayak umum kurang menyadari bagaimana warisan budaya itu ada dan harus dilestarikan. Kenyataan yang obyektif telah memperlihatkan bahwa wilayah daratan Indonesia dipenuhi oleh peninggalan budaya masa lampau baik peninggalan zaman prasejarah maupun zaman sejarah yang merupakan warisan budaya di Indonesia, dan memiliki potensi yang cukup penting untuk dikembangkan agar dapat memberikan kontribusi nyata bagi kesejahteraan masyarakat. Ki Hajar Dewantara mengemukakan bahwa kebudayaan merupakan buah budi manusia yaitu hasil perjuangan manusia terhadap dua pengaruh yang kuat, yakni pengaruh zaman dan alam yang merupakan bukti kejayaan hidup manusia untuk mengatasi berbagai rintangan dan kesukaran di dalam hidup dan kehidupannya untuk mencapai keselamatan dan kebahagiaan yang bersifat tertib dan damai. Kebudayaan juga dapat diartikan sebagai seluruh cara kehidupan 
masyarakat dalam berbagai aspek pengarah perkembangan kebudayaan kehidupan yang meliputi cara-cara berperilaku, kepercayaan, sikap dan juga hasil dari kegiatan manusia yang khas untuk suatu masyarakat atau kelompok penduduk tertentu. Manusia memelihara kebudayaan untuk menghadapi masalah dan persoalan yang mereka hadapi (Abraham Nurcahyo, 2011: 7).

Berbagai kebudayaan di Indonesia salah satunya merupakan warisan dari kehidupan masa lampau. Kebudayaan tersebut muncul pada masa kehidupan nenek moyang bangsa Indonesia. Kebudayaan yang diwariskan adalah berbagai macam peninggalan benda prasejarah. Peninggalan tersebut pada masa lampau digunakan oleh nenek moyang bangsa Indonesia sebagai alat pemenuhan kebutuhan sehari-sehari. Sebagaimana yang telah diuraikan pada paragraf sebelumnya bahwa kebudayaan merupakan hasil dari karya manusia itu sendiri untuk mengatasi tantangan dan kesukaran dalam hidup guna mencapai tujuan yang diinginkan.

Peninggalan kebudayaan yang ada di Indonesia hendaknya dijaga dan dilestarikan. Sebuah peninggalan sejarah memiliki arti yang penting untuk sebuah bangsa. Dalam hal ini diperlukan kesadaran sejarah yang ditanamkan pada kehidupan bermasyarakat terutama pada generasi muda yang nantinya akan menjadi penerus generasi sebelumnya. Kesadaran sejarah berfungsi sebagai alat pengikat dan nasional Indonesia yang tidak hanya bertumpu pada apa yang telah diwariskan oleh nenek moyang bangsa Indonesia itu sendiri (Nurhidayati dan Abraham Nurcahyo, 2012: 26-27). Pada saat ini, peninggalan bersejarah di Indonesia kurang dijaga dan dirawat serta kurang dikenal oleh masyarakat. Maka dari itu diperlukan sosialisasi untuk pengenalan peninggalanpeninggalan bersejarah tersebut terutama pada pelajar yang akan menjadi penerus bangsa kita serta kepedulian pada masyarakat untuk melestarikannya.

Dapat dikatakan peninggalan sejarah merupakan kekayaan bangsa yang tak ternilai harganya. Semakin lama atau semakin tua, nilainya justru semakin tinggi. Semakin langka suatu peninggalan bersejarah juga semakin tinggi nilainya. Peninggalan-peninggalan bersejarah sangat bermanfaat sebagai bahan studi atau penelitian. Selain itu peninggalan prasejarah juga dapat dijadikan sebagai obyek wisata. Karena begitu pentingnya peninggalan bersejarah maka perlu diadakan upaya pelestarian.

Ditemukannya berbagai peninggalan di gua-gua pada daerah Gunung Sewu yang menunjukkan kehidupan masa lampau. Marwati Djoened mengungkapkan daerah ini terletak di sebagian pegunungan kapur kira-kira 90 km di daerah Gunung Sewu dan 20-25 km dari pantai menyerong ke daerah pedalaman dan meliputi sebanyak 135 buah 
situs-situs prasejarah. Situs-situs ini berada di bagian timur sekitar daerah-daerah di Jawa Timur, yaitu Punung, Donorojo, Pringkuku dan sebagian kecil lagi terletak di bagian tengah dan barat wilayah penelitian. Misalnya di Punung terdapat Gua terus dan Gua Tabuhan, merupakan pusat perkembangan yang meliputi, segi pemukiman, teknologi, perdagangan dan lain-lain yang meliputi, aspek kehidupan pada masa lampau.

Mengingat di daerah Punung banyak ditemukan benda peninggalan purbakala sehingga dibangunlah sebuah museum lokal di wilayah Kabupaten Pacitan yaitu Museum Buwono Keling. Museum ini dibangun pada tahun 1996 di Desa Mantren Kecamatan Punung Kabupaten Pacitan. Museum ini digunakan untuk menyimpan benda-benda purbakala yang ditemukan di daerah Pacitan khususnya di daerah Punung sendiri. Museum ini dapat digunakan sebagai sarana rekreatif maupun edukatif.

Museum memilki banyak pengertian, salah satu pengertian museum adalah lembaga tempat penyimpanan, perawatan, pengamanan, dan pemanfaatan benda-benda bukti materiil hasil budaya manusia serta alam dan lingkungannya guna menunjang upaya perlindungan dan pelestarian kekayaan budaya bangsa. Adanya Museum ini dapat memberikan manfaat yang baik, karena memberikan dampak positif utamanya bagi sejarah perjalanan peradaban manusia juga masyarakat suatu bangsa. Museum juga bermanfaat sebagai media informasi budaya dalam upaya meningkatkan kualitas dan kuantitas pendidikan bagi mahasiswa maupun pelajar terutama di Kabupaten Pacitan sendiri dan masyarakat Indonesia khususnya.

Dengan demikian, museum dapat lebih mempertebal kecintaannya terhadap nilai-nilai hasil budaya bangsa. Dilain pihak dapat kita lihat pada bidang sosial ekonomi masyarakat mendapat nilai tambah dari pergerakan kunjungan masyarakat atau wisatawan ke Museum, dimana memiliki tujuan yang ingin meningkatkan jumlah pengunjung serta meningkatkan apresiasi dan kepedulian masyarakat terhadap warisan budaya bangsa.

Sekarang ini kondisi museummuseum di Indonesia banyak yang memprihatinkan. Rata-rata penyebab utama dari keadaan ini adalah biaya yang sangat minim untuk pengelolaan museum itu sendiri. Salah satunya museum lokal di Kabupaten Pacitan yaitu Museum Buwono Keling. Kondisi dari museum ini begitu memprihatinkan, bahkan sebagian koleksi museum Buwono Keling disimpan di rumah penjaga museum.

Hal ini dilakukan karena keadaan museum yang mengkhawatirkan jika semua koleksi tetap dibiarkan disana. Museum ini merupakan museum purbakala dan diperuntukkan bagi masyarakat umum. Museum ini berfungsi untuk mengumpul- 
kan, merawat, dan menyajikan serta melestarikan warisan budaya masyarakat untuk tujuan studi, penelitian dan kesenangan atau hiburan.

Melihat keadaan museum yang tidak terawat dan tidak berfungsi dengan baik maka seharusnya pemerintah segera memberikan penanganan agar museum tidak terbengkalai. Diperlukan penerapan kebijakan dalam penanganan masalah ini. Peran pemerintah sangat dibutuhkan mengingat museum ini adalah bukan museum pribadi.

Kebijakan yang diharapkan bersifat membangun hendakanya benar-benar dilaksanakan. Sehingga permasalahan terbengkalainya objek segera teratasi. Jika dibiarkan berlarut-larut maka akan berakibat fatal bagi objek itu sendiri maupun pihak yang bertanggung jawab. Dimana objek museum yang seharusnya menjadi tempat untuk pelestarian justru menjadi beralih fungsi menjadi merusak.

Misalnya hal-hal yang dapat dilakukan dalam pelaksanaan kebijakan dengan upaya melestarikan benda perbakala di museum adalah melakukan pendataaan dan pencatatan berbagai peninggalan sejarah, mengumpulkan bendabenda bersejarah dan disimpan kemudian dirawat dan dijaga agar tidak rusak. Jika usia benda sudah lumayan tua dapat dilakukan pemugaran atau penataan kembali. Untuk dapat melestarikan peninggalan tersebut diperlukan kerjasama antara pemerintah, pakar, budayawan serta masyarakat sendiri.

Kenyataan yang dapat kita lihat dan kita rasakan kebijakan yang sebenarnya digunakan untuk kesejahteraan dan kepentingan umum sering kali disalah gunakan untuk kepentingan oknum tertentu untuk kepentingan bidang lainnya. Sehubungan dengan ini museum yang harusnya menjadi icon penting di Kabupaten Pacitan dan layak dijaga dirawat dan dilindungi justru menjadi rusak dan kurang mendapat perhatian pemerintah.

Hal ini menarik untuk diteliti melihat kondisi museum yang seharusnya dijaga dan dirawat justru memprihatinkan. Sehingga menimbulkan keingintahuan tentang tidak lanjut serta kebijakan yang diterapkan oleh pemerintah Kabupaten Pacitan terhadap Museum Buwono Keling.

\section{Tinjauan Pustaka}

\section{A. Kebijakan Pemerintah}

Manusia tidak bisa lepas dari dari faktor sosio-budaya, dan didalamnya juga pasti tidak lepas dari masalah-masalah yang muncul. Untuk itu, pemerintah daerah yang berwenang dalam mendorong kemajuan daerahnya terutama dalam bidang budaya kiranya harus peka terhadap apa yang terjadi pada lingkungan sosio-budaya.

Sehingga, pemerintah dapat dengan segera mencari solusi dari permasalahan yang timbul, baik itu masalah intern maupun ekstern dari budaya itu sendiri. Pemecahan masalah ini identik dengan 
sebuah kebijakan yang bertujuan untuk memajukan atau memulihkan kembali objek yang telah bermasalah.

Peranan Pemerintah Daerah dalam perencanaan dan pelaksanaan sebuah kebijakan sangat penting untuk menghindari permasalahan dalam penerapannya. Sehingga diperlukan kebijakan yang tepat oleh pemerintah. Kebijakan muncul dikarenakan adanya suatu persoalan atau masalah yang tidak bisa diatasi dengan hukum perdata. Dibutuhkan suatu rumusan oleh pemerintah untuk mengatasi masalah tersebut.

Mengingat Indonesia merupakan negara yang berdaulat, maka sudah semestinya pemerintah berkewajiban untuk melindungi kepentingan masyarakat termasuk melingdungi warisan budaya berupa warisan sejarah maupun prasejarah. Menurut Sri Edi Tjahjo Kuntjoro (dalam Soebijantoro, 2012: 104) salah satu wujud tanggung jawab pemerintah tersebut adalah dengan terbitnya sebuah undang-undang yaitu Undang-Undang Cagar Budaya dan dalam pelaksanaannya Undang-Undang cagar budaya ini tidak mudah untuk dilakukan secara optimal.

Hal ini ditunjukkan dengan beberapa hal kasus yang terjadi. Misalnya salah kelola terhadap benda-benda cagar budaya, dan sering kita lihat rendahnya minat masyarakat untuk berkunjung ke sebuah museum. Kebijakan ini memiliki beberapa pengertian, misalnya Taliziduhu
(2003: 493) berpendapat bahwa kebijakan dapat diartikan sebagai pilihan terbaik dalam batas-batas kompetensi aktor atau lembaga yang bersangkutan secara formal mengikat dan kebijaksanaan yang juga merupakan pilihan terbaik namun berdasarkan hati nurani dalam memecahkan suatu masalah yang secara etik dan moral yang mengikat.

Dalam Kamus Besar Ilmu Pengetahuan kebijakan diartikan sebagai putusan atau perilaku penilaian yang arif dalam penggunaan pengetahuan dalam perilaku kehidupan sehari-hari (Dagun, 2006: 463). Akhir-akhir ini kajian kebijakan menjadi trend ketika pemerintah memerlukan banyak pertimbangan dan alternatif kebijakan untuk menyelesaikan masalah publik yang semakin kompleks.

Masalah ini lebih membutuhkan ekstra perhatian pemerintah daripada masalah klasik yang sederhana dapat dihadapi dengan pengalaman pemerintah sebelumnya. Saat masalah yang tidak lazim pemerintah membutuhkan alternatif yang berbeda dari kebijakan secara berbeda. Dimana terdapat analisis kebijakan yang sederhana dan langsung diidentikan dengan metode untuk mengembangkan alternatif kebijakan.

Kebijakan menurut Thomas R. Dye (dalam Dwiyanto Indiahono 2009: 17) adalah whatever goverments choose to do or not do. Dapat diartikan, bahwa apapun kegiatan pemerintah baik yang eksplisit 
maupun implisit merupakan kebijakan, lebih jelasnya adalah suatu kegiatan apapun yang dipilih oleh pemerintah untuk dilakukan atau tidak dilakukan untuk pemecahan suatu masalah. Pernyataan ini memiliki dua hal penting, yang Pertama, bahwa kebijakan harus dilakukan oleh pemerintah. Kedua, kebijakan tersebut mengandung pilihan dilakukan atau tidak dilakukan oleh pemerintah.

Pendapat lain juga diungkapkan oleh Harold D. Lasswell dan Abraham Kaplan (dalam M. Irfan Islamy 2003: 15) bahwa kebijaksanaan sebagai a projected program of goals, values, and practices. Jika diterjemahkan dalam bahasa Indonesia bahwa kebijakan adalah suatu program pencapaian tujuan, nilai-nilai dan praktekpratek yang terarah.

Kebijakan memuat 3 elemen yaitu identifikasi dari tujuan yang ingin dicapai, taktik atau strategi dari berbagai langkah untuk mencapai tujuan yang diinginkan dan penyediaan berbagai input untuk memungkinkan pelaksanaan secara nyata dari taktik atau sebuah strategi (Amara Raksasataya dalam M. Irfan Islamy, 2003: 17). Dapat dikatakan kebijakan sebagai suatu taktik dan strategi yang diarahkan untuk mencapai suatu tujuan tertentu yang diinginkan.Berdasarkan beberapa pengertian dari para ahli akhirnya dalam suatu glossary dibidang administrasi negara, kebijakan diartikan, sebagai berikut:
1. The organizing framework of purposes and rationales for government programs that deal with specified societal problems (susunan rancangan tujuan-tujuan dan dasar-dasar pertimbangan program pemerintah yang berhubungan dengan masalah-masalah tertentu yang dihadapi masyarakat).

2. Whatever governments choose to do or not to do (apapun yang dipilih pemerintah untuk dilakukan atau tidak dilakukan).

3. The complex programs enacted and implemented by government (masalahmasalah yang kompleks yang dinyatakan dan dilaksanakan oleh pemerintah). Hal ini diungkapkan oleh M. Irfan Islamy. 2003: 20).

Dari beberapa pendapat di atas, dapat disimpulkan pengertian kebijakan bahwa suatu kebijakan harus didasarkan pada kepentingan umum dan kebijakan adalah suatu serangkaian tindakan dari pemerintah yang ditetapkan dan dilaksanakan atau tidak dilaksanakan oleh pemerintah yang mempunyai tujuan tertentu demi kepentingan umum atau kepentingan masyarakat.

\section{B. Pelestarian Museum}

\section{Pelestarian}

Pelestarian secara umum dapat didefinisikan sebagai suatu usaha atau kegiatan untuk merawat, melindungi dan mengembangkan suatu objek yang memiliki nilai guna untuk dilestarikan. Objek 
pelestarian ini identik dengan kebudayaankebudayaan di Indonesia yang dapat dijadikan sarana edukatif maupun rekreatif. Sebelum muncul kegiatan pelestarian budaya, manusia memiliki kesadaran akan adanya sejarah. Dengan kesadaran akan sejarah manusia menyadari pengalaman masa lampau dan menyadari bahwa kehidupan sekarang ini baik kehidupan individu maupun masyarakat serta kebudayaan senantiasa bersumber dan berakar pada masa lampau yang akhirnya dapat membentuk kehidupan kita yang sekarang ini maupun yang akan datang (A. Daliman, 2012: 38).

Budaya yang dimaksud dan dikembangkan oleh para ahli pada pembahasan ini adalah budaya yang berhubungan dengan benda-benda peninggalan nenek moyang bangsa Indonesia. Misalnya peralatan yang digunakan oleh manusia purba pada masa lampau untuk berburu, meramu dan lain sebagainya.

Dalam hal ini para peneliti budaya atau benda peninggalan masa lampau menggunakan ilmu arkeologi atau dapat disebut dengan ilmu purbakala. Ilmu ini mempelajari tentang warisan masa lalu yang berupa artefak atau benda visual (Abd. Rahman Hamid dan Muh. Saleh Madjid, 2011: 26). Benda visual yang dimaksud misalnya berupa bangunan atau benda yang tersimpan di dalam tanah yang dikeluarkan dengan penggalian (ekskavasi).
Peninggalan dari masa prasejarah ini yang terpenting misalnya adalah kapak-kapak dalam berbagai perkembangannya (chopper, pebble, persegi, lonjong) dapat memberikan petunjuk tingkat kehidupan dan perekonomia pada masa-masa paleolitikum, mesolitikum, dan neolitikum (Aminudin Kasdi, 2003: 59).

Dalam Pasal 1 Angka 22 UU Nomor 11 Tahun 2010 Tentang Cagar Budaya dijelaskan pelestarian adalah upaya dinamis untuk mempertahankan keberadaan cagar budaya dan nilainya dengan cara melindungi, mengembangkan, dan memanfaatkannya.

\section{Museum}

Menurut Kamus Besar Ilmu Pengetahuan museum merupakan gedung yang digunakan untuk menyimpan dan memamerkan benda-benda yang pantas mendapat perhatian umum seperti peninggalan sejarah, seni dan ilmu pengetahua lainnya (Dagun. 2006: 693). Kata Museum berawal dari cerita Candi para Dewi Muse, Orang Yunani Kuno membangun sebuah candi kecil bagi Sembilan Dewi Muse (Dewi Pengkajian) di atas sebuah bukit kecil di luar kota Athena.

Setiap Dewi mempunyai pengikut yang sering memberinya hadiah. Ditahun 280 SM Raja Ptolemy di Mesir membuka museum di Istananya di kota Iskandariah, dimana para Sarjana terbesar pada zaman itu bertemu dan bekerja. Muse sendiri berarti rumah pemujaan bagi sembilan 
bersaudara (mousi), anak-anak Dewa Zeus yang melambangkan seni murni dan ilmu pengetahuan. Bangunan berupa gedung besar yang ditempatkan di kompleks istana itu digunakan sebagai pusat penelitian, tempat kuliah, tempat tinggal para cendekiawan, perpustakaan, tempat penyimpanan kumpulan benda biologi, kebudayaan, dan benda lain (Ensiklopdia Nasional Indonesia, 1990: 100).

Pengertian lain Museum adalah suatu lembaga yang diciptakan oleh manusia apakah itu dalam bentuk bangunan, dalam bentuk norma-norma perilaku, kebiasaan ataupun adat istiadat dan lembaga tersebut dianggap bermanfaat bagi kehidupan sehari-hari (Depdikbud, 1993: 3).

Definisi yang diberikan International Council of Museums, bahwa museum adalah institusi permanen, nirlaba atau tidak mencari keuntungan, melayani kebutuhan publik dengan sifat terbuka, dengan cara melakukan usaha pengoleksian, mengkonservasi, melakukan penelitian, mengkomunikasikan, dan memamerkan benda nyata kepada masyarakat untuk kebutuhan studi, pendidikan, dan kesenangan (rekreasi).

Museum adalah sebuah lembaga tetap yang tidak mencari keuntungan pribadi belaka, melayani masyarakat dan perkembangannya, terbuka untuk umum yang memperoleh, merawat, menghubungkan dan memamerkan untuk tujuan studi, pendidikan, dan kesenangan (kepuasan batin), barang-barang pembuktian manusia, dan lingkungannya (anonim Situs Museum Trinil: 4).

\section{Jenis Museum}

Berdasarkan sifat kepemilikan museum dapat dibagi menjadi 3 jenis museum, antara lain :

a) Museum Pemerintahan terdiri dari Museum Nasional yang biayanya ditanggung pemerintah pusat, museum provinsi yang dananya di dapat dari Pemerintah Provinsi, museum kota besar dan kota kecil yang dibiayai oleh Pemerintah Kota.

b) Museum swasta atau museum non Pemerintahan, biayanya di dapat dari pihak swasta, juga ada museum-museum kecil yang didanai oleh para komunitas sukarelawan.

c) Museum Pribadi atau Museum Keluarga, biayanya didanai oleh dana pribadi atau dana keluarga. Selain itu dana didapat pula dari sumbangan sumbangan yang dapat berbentuk uang, aset-aset permodalan, pelayanan, dan lain-lain. Di Indonesia pengelolaan museum, pada umumnya dilakukan oleh pemerintah.

Berdasarkan koleksi yang dimiliki, terdapat dua jenis museum yaitu:

a) Museum Umum, museum yang koleksinya terdiri dari kumpulan bukti material manusia dan atau lingkungannya yang berkaitan dengan 
berbagai cabang seni, disiplin ilmu dan teknologi.

b) Museum Khusus, museum yang koleksinya terdiri dari kumpulan bukti material manusia atau lingkungannya yang berkaitan dengan satu cabang seni, satu cabang ilmu atau satu cabang teknologi.

\section{Berdasarkan kedudukannya}

museum terbagi menjadi tiga jenis, yaitu :

a) Museum Nasional, museum yang koleksinya terdiri dari kumpulan benda yang berasal, mewakili dan berkaitan dengan bukti material manusia dan atau lingkungannya dari seluruh wilayah Indonesia yang bernilai nasional.

b) Museum Propinsi, museum yang koleksinya terdiri dari kumpulan benda yang berasal, mewakili dan berkaitan dengan bukti material manusia dan atau lingkungannya dari wilayah propinsi dimana museum berada.

c) Museum Lokal, museum yang koleksinya terdiri dari kumpulan benda yang berasal, mewakili dan berkaitan dengan bukti material manusia dan atau lingkungannya dari wilayah kabupaten atau kotamadya dimana museum tersebut berada.

Sehubungan dengan hal ini Museum Buwono Keling di Kecamatan Punung Kabupaten Pacitan termasuk ke dalam museum lokal, dimana museum ini didirikan di dekat lahan dekat kompleks bersejarah atau bekas peninggalan kepurbakalaan. Di dalam museum disimpan koleksi berasaldari hasil penggalian dan pengumpulan yang berasal dari kompleks tersebut.

\section{Fungsi Museum}

Berdasarkan Peraturan Pemerintah Nomor 19 Tahun 1995 dalam Pedoman Museum Indoneisa, 2008. museum memiliki tugas menyimpan, merawat, mengamankan dan memanfaatkan koleksi museum berupa benda cagar budaya. Dengan demikian museum memiliki dua fungsi besar yaitu :

a) Sebagai tempat pelestarian, museum harus melaksanakan kegiatan sebagai berikut :

1) Penyimpanan, yang meliputi pengumpulan benda untuk menjadi koleksi, pencatatan koleksi, sistem penomoran dan penataan koleksi.

2) Perawatan, yang meliputi kegiatan mencegah dan menanggulangi kerusakan koleksi.

3) Pengamanan, yang meliputi kegiatan perlindungan untuk menjaga koleksi dari gangguan atau kerusakan oleh faktor alam dan ulah manusia.

b) Sebagai sumber informasi, museum melaksanakan kegiatan pemanfaatan melalui penelitian dan penyajian.

1) Penelitian untuk mengembangkan kebudayaan nasional, ilmu pengetahuan dan teknologi.

2) Penyajian harus tetap memperhatikan aspek pelestarian dan pengamanannya. 
Secara umum fungsi museum adalah sebagai pusat dokumentasi dan penelitian ilmiah, pusat penyaluran ilmu untuk masyarakat, tempat penikmatan karya seni, tempat perkenalan kebudayaan antar daerah dan antar bangsa, dan sebagai obyek wisata. Di samping itu museum juga berfungsi sebagai media pembinaan pendidikan kesenian dan ilmu pengetahuan, suaka alam dan budaya, sejarah manusia, alam dan kebudayaan, serta sarana untuk pembinaan mental agama.

Dengan demikian, museum dapat menjadi bahan studi untuk kalangan akademis, dokumentasi kekhasan masyarakat tertentu, ataupun dokumentasi terhadap pemikiran imajinatif di masa depan.

\section{Tugas Museum}

a) Mengumpulkan, memelihara, merawat, mengawetkan benda-benda yang ada hubungannya dengan kebudayaan dari ilmu pengetahuan.

b) Menyelidiki, memamerkan dan menerangkan arti benda tersebut kepada para pengunjungnya (anonim Situs Museum Trinil: 5).

Berdasarkan beberapa pengertian diatas, maka dapat ditarik kesimpulan bahwa museum adalah suatu badan tetap yang terdiri dari satu atau sekumpulan bangunan yang mempunyai ruanganruangan pameran tetap yang diusahakan untuk kepentingan umum dengan tujuan mengumpulkan, memelihara, menyelidiki dan memamerkan warisan budaya khususnya untuk para generasi muda dan sebagai bukti sejarah dan kebudayaan yang dimiliki suatu bangsa.

Dengan demikian, pelestarian museum adalah suatu usaha atau kegiatan untuk merawat, melindungi dan mengembangkan suatu lembaga yang bersifat tidak tetap dan tidak mencari keuntungan dalam melayani masyarakat dengan tujuan pengkajian, pendidikan dan kesenangan.

\section{Metode Penelitian}

Menurut Bogdan dan Guba (dalam Uhar Suharsaputra, 2012: 179) penelitian kualitatif atau dapat disebut naturalistic inquiry merupakan prosedur penelitian yang menghasilkan data deskriptif berupa kata-kata tertulis atau lisan dari orangorang dan perilaku yang diamati. Pendekatan kualitatif ini dipilih karena bersifat mampu mendeskripsikan suatu fenomena atau gejala sosial yang menjadi permasalahan dalam masyarakat atau lembaga tertentu yang sulit dipahami.

Sehingga dengan menggunakan pendekatan kualitatif ini peneliti dapat mengungkap dan memperoleh data tentang Kebijakan Pemerintah Kabupaten Pacitan dalam Pelestarian Museum Buwono Keling di Kecamatan Punung Kabupaten Pacitan. Jenis penelitian kasus (case study) adalah penelitian tentang status subyek penelitian yang berkenan dengan suatu fase spesifik dari keseluruhan personalitas baik itu 
individu, kelompok, lembaga, maupun masyarakat (Maxfield dalam Moh. Nazir 2011: 57). Tujuan dari studi kasus ini adalah untuk memberikan gambaran secara mendetail tentang latar belakang, sifat-sifat, serta karakter yang khas dari kasus individu ataupun kelompok sosial dalam masyarakat kemudian dideskripsikan secara umum.

Pengumpulan data dapat dilakukan dalam berbagai sumber. Bila dilihat dari sumber datanya, maka pengumpulan data dapat menggunakan sumber primer dan sumber sekunder Sugiyono (2013: 308). Sumber data primer adalah sumber-sumber dasar yang merupakan bukti atau saksi utama dari kejadian yang lalu (Moh. Nazir, 2011: 50). Data ini berupa catatan resmi ataupun suatu keterangan dari saksi mata.

Sugiyono (2013: 309) mengatakan sumber data sekunder merupakan sumber yang tidak langsung memberikan data atau informasi kepada peneliti. Namun data diperoleh dari orang lain atau melalui dokumen yang ditemukan peneliti. Dalam penelitian ini menggunakan sumber dari pustaka buku kebudayaan, arkeologi, foto dokumentasi juga dokumen profil Museum Buwono Keling sehingga dapat mendukung dan memperlancar penelitian ini.

Teknik pengumpulan data yang digunakan adalah observasi yang merupakan metode atau cara menganalisis dan mengadakan pencatatan secara sistematis mengenai tingkah laku yang terjadi dengan melihat atau mengamati individu atau kelompok secara langsung (Ngalim Purwanto dalam Basrowi dan Suwandi, 2008: 93-94). Menurut Haris Herdiansyah (2011: 131) observasi adalah suatu kegiatan mencari data yang dapat digunakan untuk memberikan suatu kesimpulan atau diagnosis.

Teknik pengumpulan data yang kedua wawancara adalah proses memperoleh keterangan untuk tujuan penelitian dengan cara tanya jawab sambil bertatap muka antara pewawancara dengan informan atau orang yang diwawancarai dengan atau tanpa menggunakan pedoman wawancara (Burhan Bungin, 2007: 108). Teknik pengumpulan data yang ketiga Dokumenasi ialah salah satu metode pengumpulan data kualitatif dengan melihat atau menganalisis dokumen-dokumen yang dibuat oleh subjek sendiri atau oleh orang lain tentang subjek yang bersangkutan dan dapat melalui media tertulis (Haris Herdiansyah, 2011: 143).

Adapun analisis data yang digunakan dalam penelitian ini adalah menggunakan analisis data kualitatif dari Miles dan Huberman (1992: 16-19) yaitu reduksi data dapat diartikan sebagai proses pemilihan, pemusatan perhatian pada penyederhanaan, pengabstrakan, dan transformasi data yang belum diolah dari catatan-catatan tertulis di lapangan, Sajian data merupakan sekumpulan informasi tersusun yang memberi kemungkinan adanya penarikan kesimpulan dan 
pengambilan tindakan dan Verifikasi ialah proses penarikan simpulan dari keseluruhan kegiatan yang dilaksanakan. Tahap kesimpulan yang dikemukakan pada tahap awal, di dukung oleh bukti yang valid dan konsisten saat peneliti mengumpulkan data, dan kesimpulan yang dikemukakan merupakan kesimpulan yang akurat.

\section{Hasil Dan Pembahasan}

\section{A. Profil Museum Buwono Keling}

Museum adalah lembaga, tempat penyimpanan, perawatan, pengamanan, dan pemanfaatan benda-benda bukti materiil hasil budaya manusia serta alam dan lingkungannya guna menunjang upaya perlindungan dan pelestarian kekayaan budaya bangsa. Dalam undang-undang cagar budaya museum diartikan sebagai lembaga yang berfungsi melindungi, mengembangkan, memanfaatkan koleksi berupa benda, bangunan, atau struktur yang telah ditetapkan sebagai cagar budaya atau bukan cagar budaya dan mengkomunikasikan kepada masyarakat.

Bekaitan dengan hal ini, pemerintah Kabupaten Pacitan membangun sebuah Museum yang difungsikan sebagai tempat penyimpanan, perawatan dan pegamanan benda-benda peninggalan pra sejarah yang ditemukan di wilayah Kabupaten Pacitan. Museum tersebut merupakan museum arkeologi yang diberi nama Museum Buwono Keling. Museum Buwono Keling adalah museum yang dibangun di Kecamatan Punung Kabupaten Pacitan.
Museum ini dibangun pada bulan April tahun 1995 oleh suaka peninggalan sejarah purbakala Jawa Timur, dan difungsikan pada tahun 1996 yakni sebagai tempat penyimpanan benda prasejarah di temukan di tempat yang tidak jauh dari dibangunnya Museum tersebut. Tanah yang digunakan dalam pembangunan Museum adalah tanah milik Pemerintah Kabupaten Pacitan dengan luas $50 \times 20 m^{2}$ dengan luas bangunan Museum $16 \times 16 \mathrm{~m}^{2}$.

Bangunan ini tidak terlalu besar dan luas tetapi koleksi yang dimiliki oleh Museum cukup banyak, bahkan sebagian benda koleksi dibawa ke Trowulan. Koleksi yang berada di dalam museum yaitu sekitar 3.896 koleksi. Seperti diketahui bahwa keberadaan Pacitan sebagai kabupaten tak lepas dari keberadaan sejarah yang panjang. Sebab Pacitan memiliki nilai historis yang sangat kuat, terutama ketika dikaitkanmengenai situs-situs purbakala yang berada Kabupaten Pacitan ini.

Kekayaan geologi yang dimiliki Pacitan lebih unggul dibanding wilayah lain, tidak hanya di Indonesia namun juga di dunia. Sehingga saat ini Pacitan sedang menuju Geopark dunia yang diusulkan ke badan dunia UNESCO. Di ketahui pula bahwa gunung sewu secara geologis dan geografis terpisah dari wilayah Pulau Jawa lainnya dimana iklimnya kering. Relief bukit kapur, gua dan gua payung banyak terdapat di daerah ini. Cukup ideal sebagai tempat 
tinggal bagi manusia purba, dan ada banyak jenis bebatuan sileks lokal bermutu sebagai bahan baku pembuatan peralatan dan senjata. Predikat ibu kota prasejarah dunia pantas disandang Kabupaten Pacitan, karena kabupaten yang terletak di perbatasan dengan Jawa Tengah ini menyimpan ratusan lokasi situs prasejarah.

Kurang dari 261 lokasi situs prasejarah. Baik dalam tahapan eksploitasi maupun yang telah disurvei tim arkeologi. Situs-situs tersebut berada di jajaran Gunung Sewu yang tersebar mulai di Kecamatan Punung, Pringkuku, Pacitan, Kebonagung hingga Kecamatan Tulakan. Sehingga dengan begitu banyak ditemukan benda-benda peninggalan pra sejarah di daerah ini.

\section{B. Pengelolaan Museum Buwono Keling}

Pengelolaan merupakan upaya terpadu untuk melindungi mengembangkan dan memanfaatkan cagar budaya melalui kebijakan pengaturan perencaan, pelaksanaan dan pengawasan (Undangundang Cagar Budaya Tahun 2010: 5). Pengelola Museum Buwono Keling adalah langsung oleh Pemerintah Daerah Kabupaten Pacitan.

Dengan mengangkat beberapa pegawai atau staf sebagai juru pelihara dan juga sebagai penjaga museum maupun sebagai petugas administrasi. Dalam suatu pengelolaan tentunya dana juga diperlukan, guna pemeliharaan koleksi-koleksi yang terdapat pada Museum. Sehubungan dengan pengelolaan Museum, Pemerintah Kabupaten Pacitan memberikan dana operasional yang bersal dai APBD. Dana tersebut untuk perawatan Museum.

Selain itu alasan bahwa Museum Buwono Keling ini tergolong museum milik pemerintah bukan milik pribadi, sehingga dana yang digunakan untuk Museum juga didapatkan dari pemerintah daerah Kabupaten Pacitan, meski jumlah yang didapatkan tidak sesuai yang diharapkan. Sebagai biaya perawatan dan pengelolaan dirasa kurang memadai, yang menyebabkan kondisi Museum yang usianya semakin tua menjadi semakin rapuh dan memprihatinkan.

\section{Tanggapan Masyarakat terhadap Museum Buwono Keling}

Jumlah pengunjung di Museum Buwono Keling tidak selalu sama, dan sebagian besar pengunjung adalah para siswa maupun mahasiswa yang datang dari daerah sekitar maupun luar daerah Kabupaten Pacitan.

Keinginan untuk menarik minat pengunjung yang datang berkunjung ke Museum Buwono Keling dilakukan dengan cara promosi dari mulut ke mulut, dan cara sederhana dengan hanya sebatas meningkatkan fasilitas yang ada pada Museum dan juga pelayanan yang baik dari petugas di Museum. Jika untuk berencana yang lebih besar lagi tidak memungkinkan karena keterbatasan biaya anggaran yang dimiliki pihak Museum. Meskipun demikian 
namun kebanyakan orang masih lebih memilih hanya untuk sekedar rekreasi dan tidak peduli unsur dari budaya yang ada pada suatu objek wisata yang mereka kunjungi, padahal Museum Buwono Keling memilki unsur cagar budaya yang tinggi tapi mayarakat sebagian besar tidak menyadari akan hal tersebut. Keberadaan Museum Buwono Keling ini sebenarnya cukup banyak mendapatkan tanggapan positif dari masyarakat sekitar maupun msyarakat yang datang dari luar daerah.

Tanggapan positif didapatkan dari kaum pelajar, mereka mengatakan sangat terbantu dengan adanya Museum yang menyimpan benda-benda prasejarah. Mereka datang untuk melakukan penelitian ataupun untuk memenuhi tugas sekolah secara bekelompok. Masyarakat juga memberikan apresiasi yang baik terhadap keberadaan Museum Buwono Keling di Kecamatan Punung.

Sebagian masyarakat merasa bangga jika daerah mereka memiliki potensi wisata budaya dan sejarah. Sehingga dengan adanya Museum Buwono Keling tersebut dapat melestarikan unsur budaya dan juga sejarah yang seharusnya tetap dijaga keutuhan dan keasliannya.

\section{Kebijakan Pemerintah Kabupaten}

Pacitan dalam Pelestarian Museum Buwono Keling

Indonesia merupakan negara yang berdaulat, maka sudah semestinya pemerintah berkewajiban untuk melindungi kepentingan masyarakat termasuk melindungi warisan budaya berupa warisan sejarah maupun prasejarah. Dengan adanya pelestarian Museum Buwono Keling di Kecamatan Punung ini diharapkan warisan budaya yang dimilki Indonesia tidak mengalami kepunahan.

Pelestarian adalah upaya dinamis untuk mempertahankan keberadaan cagar budaya dan nilainya dengan cara melindungi, mengembangkan, dan memanfaatkannya. Dalam hal ini pemerintah berperan dalam pelestarian sebuah warisan budaya. Salah satu wujud tanggung jawab pemerintah tersebut adalah dengan terbitnya sebuah undang-undang yaitu Undang-Undang Cagar Budaya dan dalam pelaksanaannya Undang-Undang Cagar Budaya ini tidak mudah untuk dilakukan secara optimal.

Meski peraturan dan perihal yang terkandung dalam undang-undang telah dilaksanakan namun adanya Undangundang Cagar Budaya tersebut tidak membawa perubahan yang signifikan dan berarti terhadap pengelolaan dan pelestarian warisan budaya bangsa. Faktor yang diketahui sebelumnya bahwa tingkat pendidikan di Kecamatan Punung masih rendah dan rata-rata penduduk hanya lulusan SD. Sehingga untuk mensosialisasikan pentingnya warisan budaya bagi bangsa Indonesia, sulit dilakukan pada masyarakat luas untuk menumbuhkan kesadaran akan peninggalan 
prasejarah sehingga menyebabkan kegagalan dalam pengelolaan dan pelestarian Museum Buwono Keling.

Sehubungan dengan permasalahan tersebut, di era otonomi daerah merupakan kesempatan bagi pemerintah daerah itu sendiri baik itu pemerintah kota maupun kabupaten untuk mencari cara bagaimana dapat memajukan daerahnya tersebut melalui sebuah pelestarian warisan budaya. Dengan demikian diperlukan tindak lanjut yaitu berupa kebijakan-kebijakan dalam pengelolaan warisan budaya yang ada.

$$
\text { Diungkapkan oleh Harold D. }
$$

Lasswell dan Abraham Kaplan (dalam M. Irfan Islamy, 2003: 15) bahwa kebijaksanaan sebagai a projected program of goals, values, and practices. Jika diterjemahkan dalam bahasa Indonesia bahwa kebijakan adalah suatu program pencapaian tujuan, nilai-nilai dan praktekpratek yang terarah.

Sehingga kebijakan ini merupakan serangkaian tindakan dari pemerintah yang ditetapkan dan dilaksanakan atau tidak dilaksanakan oleh pemerintah yang mempunyai tujuan tertentu demi kepentingan umum atau kepentingan masyarakat. Dalam hal ini kaitannya dengan pengelolaan Museum Buwono Keling di Kecamatan Punung Kabupaten Pacitan. Dalam undang-undang cagar budaya mengenai tugas dan wewenang pada pasal 95 telah dijelaskan pada ayat 1 bahwa pemerintah daerah mempunyai tugas melakukan perlindungan, pengembangan, dan dijelaskan pula pada ayat 2 bahwa pemanfaatan cagar budaya.

Pemerintah daerah sesuai dengan tingkatannya mempunyai beberapa tugas, antara lain:

1. Mewujudkan, menumbuhkan, mengembangkan, serta meningkatkan kesadaran dan tanggung jawab akan adanya cagar budaya dan hak ataupun kewajiban masyarakat dalam pengelolaan cagar budaya.

2. Mengembangkan dan menerapkan kebijakan yang dapat menjamin terlindunginya dan termanfaatkannya cagar budaya yang ada.

3. Menyelenggarakan penelitian dan pengembangan cagar budaya.

4. Menyediakan informasi cagar budaya untuk masyarakat.

5. Menyelenggarakan promosi cagar budaya.

6. Memfasilitasi setiap orang dalam melaksanakan pemanfaatan dan promosi cagar budaya.

7. Menyelenggarakan penanggulangan bencana dalam keadaan darurat untuk benda, bangunan, struktur, situs dankawasan yang telah dinyatakan sebagai cagar budaya serta memberikan dukungan terhadap daerah yang mengalami bencana.

8. Melakukan pengawasan, pemantauan, dan evaluasi terhadap pelestarian warisan budaya. 
9. Mengalokasikan dana bagi kepentingan pelestarian cagar budaya (UndangUndang Cagar Budaya, 2011: 32-33).

Dengan demikian, Pemerintah Kabupaten Pacitan memberlakukan kebijakan dalam pengelolaan dan pemeliharaan museum. Kebijakan-kebijakan tersebut disesuaikan dengan Peraturan Menteri Kebudayaan dan Pariwisata nomor: PM45/UM.001/MKP/2009 tentang Permuseuman, dan juga Peraturan Bupati Pacitan Nomor 43 Tahun 2007 tentang Uraian Tugas, Fungsi, dan Tata Kerja Dinas Kebudayaan Pariwisata Pemuda dan Olahraga Kabupaten. Agar kebijakan yang terbentuk sesuai dengan tujuan dan fungsi yang diinginkan.

Mendirikan museum tidak terlalu sulit namun menyelenggarakan dan mengelola Museum tidaklah mudah. Pada umumnya yang dipikirkan hanya biaya untuk pendiriannya saja, tetapi kurang memperhitungkan secara matang biaya untuk kelangsungan hidup dari museum itu sendiri. Sehingga museum tersebut tidak dapat tampil dengan baik.

Bahkan sering kali sebuah museum tidak dapat melanjutkan kelangsungannya karena terbentur oleh biaya pengelolaan terutama biaya pengelolaan yang cukup besar. Terbukti dengan pengelolaan yang dilakukan oleh pemerintah, optimal atau tidaknya dapat kita simpulkan dengan melihat kondisi Museum yang memprihatinkan. Pada kenyataannya bahwa kondisi Museum Buwono Keling secara keseluruhan terlihat tua dan rapuh. Selain terjadi kebocoran saat turun hujan, angin yang bertiup kencang membuat beberapa bagian atap museum yang terbuat dari kayu terlihat roboh. Selain itu, sejumlah kayu pada bagian peneduh itu keropos dan mulai terlepas. Rusaknya atap berimbas pada bagian dalam gedung, tepat di bawah titik kerusakan, dimana bekas-bekas rembesan air terlihat jelas di dinding yang berwarna kecoklatan.

Padahal di dalam museum itu tersimpan sejumlah benda-benda peninggalan prasejarah, seperti kapak genggam, kapak perimbas, mata panah yang berasal dari situs-situs di sekitar museum mulai zaman paleolitikum, mesolitikum, dan neolitikum. Sejauh ini, Pemerintah Kabupaten Pacitan dinilai kurang peduli terhadap keberadaan Museum Buwono Keling. Kondisi Museum yang di Kecamatan Punung itu sangat memprihatinkan. Padahal dapat dikatakan bahwa Museum itu merupakan jendela masa, seharusnya kita menjaga dengan sebaik-baiknya dan juga melestarikan keberadaannya.

Pemerintah mengatakan bahwa penyebab utama permasalahan tersebut adalah sedikitnya anggaran yang dimiliki Museum maupun anggaran Pemerintah. Seharusnya Pemerintah Kabupaten Pacitan tidak mengabaikan kondisi yang sedemikian rupa. Museum itu sesuatu yang berharga jadi jangan sampai dibiarkan terbengkalai. 
Sebaiknya Pemerintah Kabupaten Pacitan segera merenovasi bangunan Museum Buwono Keling dan merelokasi koleksikoleksinya. Selain itu, harus pandai mencari cara untuk menarik perhatian pengunjung. Membutuhkan kerja keras untuk membangkitkan kecintaan masyarakat akan museum agar masyarakata turut serta dalam pelestarian Museum. Meski sebagian masyarakat yang lain kebanyakan lebih memilih hanya untuk sekedar rekreasi dan tidak peduli unsur dari budaya yang ada pada suatu objek wisata.

Namun sebagian masyarakat juga memberikan tanggapan positif terhadap keberadaan Museum Buwono Keling. Museum tidak hanya memiliki fungsi rekreatif namun edukatif. Banyak pelajar yang sering datang berkunjung ke Museum Buwono Keling. Selain untuk wisata juga untuk memenuhi tugas dari sekolah untuk observasi di Museum. Masyarakat juga merasa bangga dengan adanya Museum sebagai sarana pelestari warisan budaya.

Hal ini dapat menjadikan pertimbangan bagi Pemerintah Kabupaten Pacitan untuk segera memperbaiki atau merenovasi Museum Buwono Keling yang kondisinya sudah memprihatinkan. Mengingat fungsi Museum bermanfaat bagi masyarakat Kabupaten Pacitan.

Penutup

\section{A. Kesimpulan}

Museum Buwono Keling adalah sebuah museum arkeologi yang berada di
Dukuh Krajan Kulon Desa Mantren Kecamatan Punung Kabupaten Pacitan. Museum ini dibangun pada bulan April tahun 1995 oleh suaka peninggalan sejarah purbakala Jawa Timur, dan difungsikan pada tahun 1996 yakni sebagai tempat penyimpanan peninggalan prasejarah, seperti kapak genggam, kapak perimbas, mata panah yang berasal dari situs-situs di sekitar museum Buwono Keling dan bendabenda peninggalan tersebut mulai zaman paleolitikum, mesolitikum, dan neolitikum.

Adanya Museum Buwono Keling diharapkan dapat menjadi tempat penyimpanan cagar budaya sebagai sarana atau media dalam pelestarian peninggalan prasejarah yang seharusnya dijaga keutuhan dan keasliannya. Sehubungan dengan keberadaan museum di Kecamatan Punung Pemerintah Kabupaten Pacitan memberlakukan kebijakan dalam pengelolaan dan pemeliharaan museum, disesuaikan dengan Peraturan Menteri Kebudayaan dan Pariwisata nomor: PM. 45/UM.001 /MKP/2009 tentang Permuseuman, dan Peraturan Bupati Pacitan Nomor 43 Tahun 2007 tentang Uraian Tugas, Fungsi, dan Tata Kerja Dinas Kebudayaan Pariwisata Pemuda dan Olahraga Kabupaten.

Namun, Pemerintah Kabupaten Pacitan kurang tanggap atau tidak mempedulikan keberadaan Museum Buwono Keling. Padahal museum tersebut dapat menjadi objek wisata yang tidak 
hanya mempunyai unsur rekreatif, tetapi memiliki unsur edukatif, dan tentu dapat memberikan daya tarik bagi objek wisata di Kecamatan Punung Kabupaten Pacitan.

Kebijakan yang telah dibuat dan disepakati pihak yang bersangkutan belum terealisasi dengan maksimal. Sejauh ini Pemerintah mengatakan bahwa akan segera melakukan renovasi pada waktu dekat, dan Museum ditutup untuk sementara waktu. Untuk koleksinya sebagian dipindahkan ke rumah juru pelihara Museum.

\section{B. Saran}

Bagi Masyarakat Desa Mantren Kecamatan Punung Kabupaten Pacitan sebaiknya masyarakat ikut serta dalam upaya pelestarian budaya peniggalan masa prasejarah. Bagi Pemerintah Kabupaten Pacitan diharapkan memperhatikan pelestarian Museum, dimana Pemerintah memiliki peran sebagai pengelola Museum Buwono Keling hendaknya juga memperhatikan bagaimana kondisi Museum, baik gedung maupun koleksikoleksinya, dan dilakukan renovasi bangunan gedung yang sudah mulai rusak.

\section{Daftar Pustaka}

Abd. Rahman Hamid dan Muh. Saleh Majid. 2011. Pengantar Ilmu Sejarah. Yogyakarta: Ombak

Abraham Nurcahyo dkk. 2011. Ilmu Sosial dan Budaya Dasar. LE-Swaastika: Magetan

Aminudin Kasdi. 2003. Memahami Sejarah. Surabaya: Unesa University Press
Anonim. 1990. Ensiklopedi Nasional Indonesia Jilid 13. Jakarta: PT. Cipta Adi Pustaka

Anonim. 1993. Kecil tapi Indah (Pedoman Pendirian Museum). Jakarta: Departemen Pendidikan dan Kebudayaan Proyek Pembinaan Permuseuman Jakarta

Anonim. 2011. Undang-Undang Republik Indonesia Nomor 11 Tahun 2010 Tentang Cagar Budaya dan Penjelasannya. Trowulan: Balai Pelestarian Peninggalan Purbakala Trowulan Wilayah Kerja Provinsi Jawa Timur

Anonim. Situs Museum Trinil. Ngawi: Jawa Timur

Basrowi dan Suwandi. 2008. Memahami Penelitian Kualitatif. Jakarta: Rineka Cipta

Burhan Bungin. 2007. Penelitian Kualitatif. Jakarta: Prenada Media Group

Daliman. 2012 Manusia dan Sejarah. Yogyakarta: Ombak

Dwiyanto Indiahono. 2009. Kebijakan Publik (Berbasis Dynamic Policy Analysis). Yogyakarta: Penerbit Gava Media

Edy Sdyawati. 2007. Budaya Indonesia Kajian Arkeologi Seni dan Sejarah. Jakarta: PT. Raja Grafindo Persada

Ensiklopedia Nasional Indonesia Jilid 13. 1990. Jakarta: PT. Cipta Adi Pustaka

H. B. Sutopo. 2006. Metodologi Penelitian Kualitatif. Surakarta: Universitas Sebelas Maret

Haris Herdiansyah. 2011. Metodologi Penelitian Kualitatif untuk Ilmu-ilmu Sosial. Jakarta: Salemba Humanika

Husein Umar. 2011. Metode Penelitian Untuk skripsi dan Tesis Bisnis. Jakarta: Raja Grafindo Persada

Husnaini Usman dan Purnomo Setyadi Akbar. 2004. Metodologi Penelitian Sosial. Jakarta: Bumi Aksara

Irfan Mahmud. 2012. Warisan Sumberdaya Arkeologi dan Pembangunan. Yogyakarta: Ombak 
John W. Creswell. 2010. Research Design Pendekatan Kualitatif Kuantitatif dan Mixed. Yogyakarta: Pustaka Pelajar

M Burhan Bungin. 2007. Penelitian Kualitatif: Komunikasi Ekonomi Kebijakan Publik dan Ilmu Sosial Lainnya. Jakarta: Kencana Prenada Media Group

M.Irfan Islamy. 2003. Prinsip-Prinsip Perumusan Kebijaksanaan Negara. Jakarta: PT. Bumi Aksara

Marwati Djoened Poesponegoro dan Nugroho Notosusanto. 2008. Sejarah Nasional Indonesia I (Zaman Prasejarah di Indonesia). Jakarta: Balai Pustaka

Moh. Nazir. 2011. Metode Penelitian. Bogor: Penerbit Ghalia Indonesia

Mukhlis Paeni. 2009. Sejarah Kebudayaan Indonesia (Sistem Pengetahuan). Jakarta: Rajawali Pers

Nana Syaodih Sukmadinata. 2007. Metode Penelitian Pendidikan. Bandung: PT Remaja Rosdakarya

Oka A. Yoety. 1994. Komersialisasi Seni Budaya dalam Pariwisata. Bandung: Angkasa

P. Joko Subagyo. 2004. Metode Penelitian dalam Teori dan Praktek. Jakarta: PT Asti Mahasatya

Save M. Dagun. 2006. Kamus Besar Ilmu Pengetahuan. Jakarta: Lembaga Pengkajian Kebudayaan Nusantara

Soebijantoro. 2012. Undang-Undang Benda Cagar Budaya di Era Otonomi Daerah. Agastya: Jurnal Sejarah dan Pembelajarannya. Madiun: Program Studi Sejarah

Miles dan Huberman. 1992. Analisis Data Kualitatif. Jakarta: Penerbit Universitas Indonesia

Sugiyono. 2013. Metode Penelitian Pendidikan: Pendekatan Kuantitatif Kualitatif dan $R$ dan $D$. Bandung: Alfabeta

Taliziduhu Ndraha. 2003. Kybernology (Ilmu Pemerintahan Baru). Jakarta: PT. Rineka Cipta
Uhar Suharsaputra. 2012. Metode Penelitian Kuantitatif Kualitatif dan Tindakan. Bandung: PT Refika Aditama

Undang-Undang Republik Indonesia Nomor 11 Tahun 2010 Tentang cagar Budaya. 2011. Balai Pelestarian Peninggalan Purbakala Trowulan 